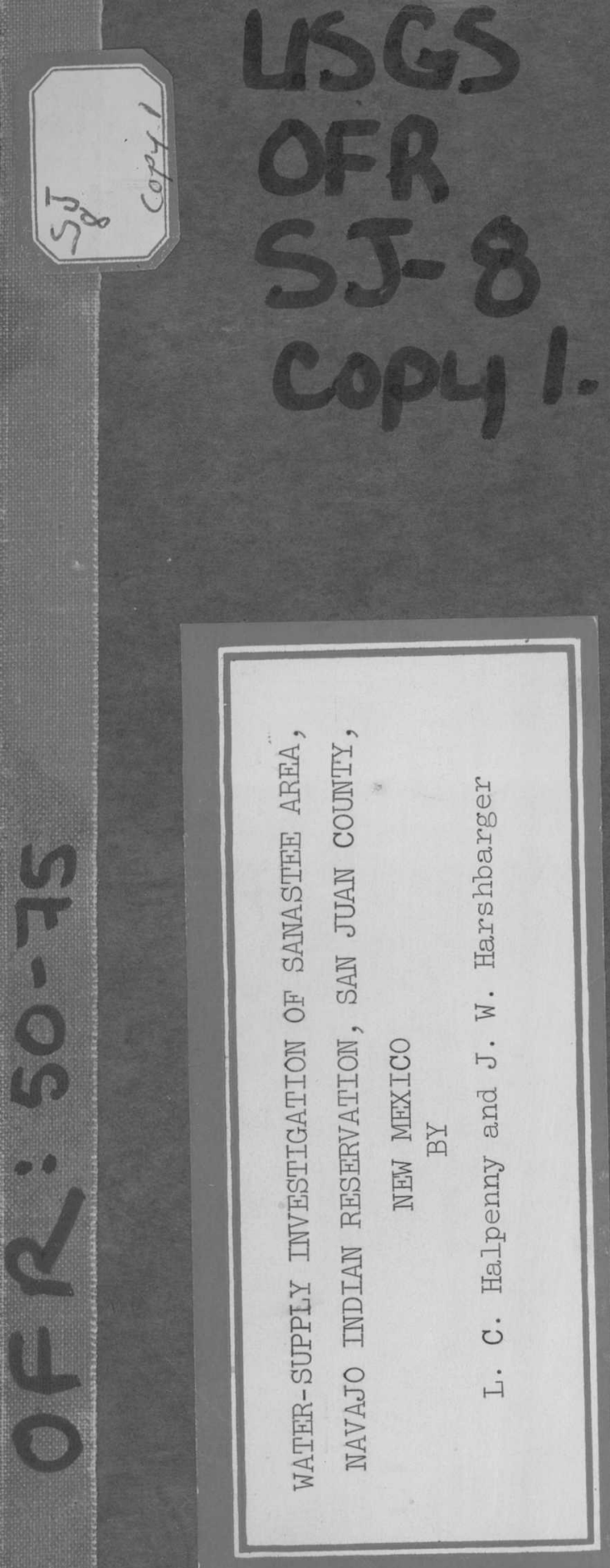

U.S. GEOLOGICAL SURVEY WRD, LIBRARY

505 MARQUETTE NW, RM 720

ALBUQUERQUE, N.M. 87102 
Water-aupply Inventigation of Sanastee area, Navajo Indian Heservation, San Juan County, Nenx Moxdeo

By

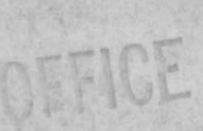

L. C. Halpenny and J. I. Harshbarger

By

\section{J. D. Here}

With a section on Quality of Water

U.S. GEOLOGICAL SURVEY

WRD, LIBRARY

S05 MARQUETTE NW, RM TW

ALUQUERQUE, N.M. 87102

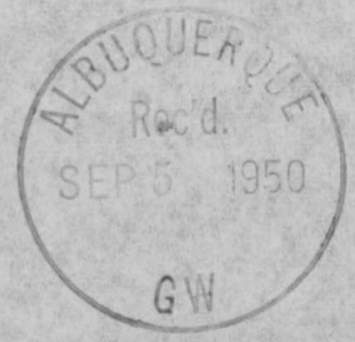

Prepared in coojeration with Hea Hexdco State Ingtneer Abizquenqua, Niew Mexcleo

$$
\begin{aligned}
& \text { July } 1950 \\
& 50.75
\end{aligned}
$$




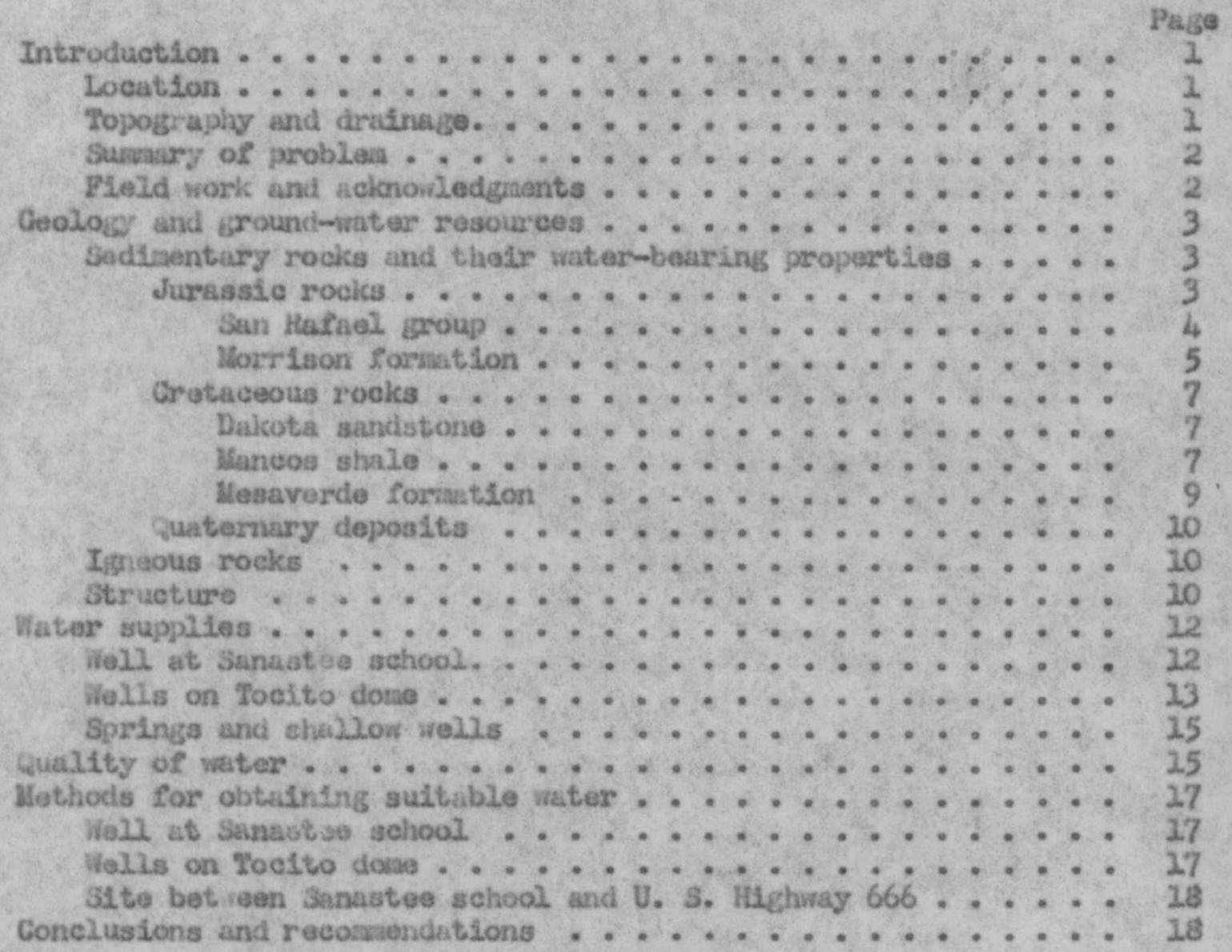

\section{THLSTL:TOR3}

Plate 1. Map of Sanatee azea, Sein Jwas County, N. Hax., shoiring geology and Locations of wells and aprings. . . . 3

Figure 1. Diagraaratido sketch showing Intertonguing ruiktions of units of tha Mancos shale and Nesavarde forwision. . 3 2. Graphs showing rusults of teats on wo 11 1215-25, Sanuatee N. Mox. ....................

\section{TABLBS}

1. Records of walls and springs - In Sanuatee area, San Juan County, H. Hex.......................... 20

2. Loigs of rulis in Sanastee area, San Juan County, H. Hex. . . . 22

3. Analsses of water sarples from walls and springs in Sanastee arau, San Juan County, N. Mex. ............. 26 


\section{WATAR-SUPPLY IIVATIGATTON OF SHUSTBS ARBA,

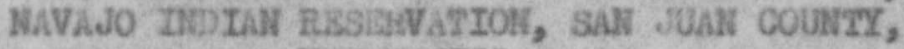 NBII $20 \times x T C O$}

By L. C. Malpenny and J. W. Harshbarger

With a section on quality of vlater

By d. D. Haia

\section{INTRODUCTIOH}

At the roqueat of the Ofrlee of Indian Arfairs the Ground Nator Branch

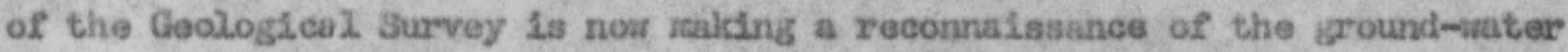
resources of the Havajo Indian Resarvation, which occuplus parts of Arizons, New Mexico, and Utah. In addition, special detalled studies are being made in areas where speclfic problens roquire inesedinte attention. This roport of the Investfgation of the Sanastee area was requested beeause the water supply for the Sanastee schood was considered unsatisfactory.

\section{Location}

The aros described in this report 11 es in the eastern part of the Navajo Indian Reservation, in San Juan County, H. Mex. The corarunity of Banastee, in the central. part of the area, is about 35 siles south of shiprock and 8 ralles west of U. S. Highway 666 along a graded road. The altitude at Sanastea is about 6,000 feet. This coraunity consists of a shall boarding sehool and a few assoejated butldíngs. The main buildings have been condeitned, and the school has not been in operatiton sines June 1949 . The nearest trading post ls about $23 / 4$ miles northeast of the school.

\section{Topography and Drainage}

The Sanastee aroa is chsricterlized by igentle slopes; in contrrast are several sinall mesas and buttes that rise alnost vertically froa the plain. The topographie rellef is modernte except In the western purt, where deep canyons 
dissoct the plain. The area is drained by Sanastee Wash and Tueito Vash, which Now eastward and enter Chaco Creek about it illes east of U. 3 . Highiay 666. Chace Creek is a tributary of the San Juan Kiver, which flows into the Colorsdo Ruver.

\section{Sumuary of Problea}

Wator for the Sanastee school has been obtakned fron a Ilowing weil that produces a sisul anount of ofl (well 12li-25, table 1). There aro two phases of the water-supply probleas (1) 042 soinstitas enters the water systea in spite of attesupts to renove it by a continuous overflou fros an elevated storage tank; and (2) overfion fron the tank and exceess water frosa the well have bean allowed to saturate the shaly ground near the achool builaings, eausing unatable conditions that have lad to ericking of the foundationa. Offlelala of the Navajo Service suggeated tio alternative aolutiona to

the problent (2) Abandon the exdating butldings and construct nea buildings withln a radius of a few hundred feat of the present site. Under this plan the Sansatev well would be plugised to seal ofr the oll, or a ner oll-free water supply would be developed. (2) Abandon the existing location and select a site nearer U. 3. Highway 666. If this plan wore followed a new well would be drilied.

If a new achool were bulit, the estimated population of the comaunity would be about 250. On the basis of a daliy per-capita consurption of 150 gallons, the total supply needed would be about 37,500 gallons per day, or about 26 gallons per minute, This is considered to be the minimum supply needed.

\section{Plold Work and Acinosiledgrents}

in area of about 175 square miles was studied in order to deterralne the aost productive aquifers, the areas of recharise, and the related staructural features. Ceologic flezd work was done by J. W. Harshbarger, assisted by 
W. 1. HeKee. Kngtheering fleld work was done by L. C. Halpenny, assiated by G. A. Lerua and H. A. Yazhe. The quality of Nater section of the report, uss written by J. D. Hea, district chemist, Guezlity of Water Branch. C. V. Theis, distríct geologist for ground-water Invest1gations in Now Mexleo, was consulted during the work and reviewed the report. C. B. Read, In eharge of the Albuquerque ofriee of the Puele Branch, Ceologite Divialon, Fevianed the section of the roport that deals with strati graphy.

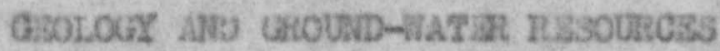

The geologie map of the Sanastea area is shoin on plate 1. The formational boundariss and structural foatures were loeated on aerial photographs and the Information was then transforsed to controllod aerial nosaics froan which the fina? sap was made.

\section{Sedinantary flocks and their Water-Beaxinis Properties}

The stratifaphic soction exposed in the Danastee area is as follovs: QU:x ALLuvion constacious (laneos shale (upper part) (Hesaverde foraation CaLrup sandstone and Dilco coal sweabers (Hancos shale (lower part) (Dakota dandstone

Juknssic

(Horrison formation

(San Flafanl group Todilto Liaestone nenber of Wanakah formation Kantrade sandstone Carnel fornation

Jurassic Rocks

The oldest rocks in the area belong to the Sun Rafrel group, of late Jurassic age, althoagh the Lovest foraution, the Carnel, does not arop out within the mapped area. Older rooks were not considered as potentlal acquifers because they lie too far beneath the Land surface, and It is balieved that 
sufficient water can be obtsined from the younger rooks. San Rafael groug

The San Fafael group incliades the Carnel formition which does not crop out In the area of this report, the Bntrada sandotone, and the Todulto 2 inestone member of the Wunukah foration. It is extremely difficult to deteraine the boundary botween the Carral fornation and the lentrada sandstone in this region. The thickness of the San Rafael jroup 1 s between 600 and 750 feet, as deternined from logs of vells $124-25$ and I21-33a. The Carnel formation is composed of red fine-grained thinbedded shaly siltstone with thin beds of fine-grained sandstone occurring at irregular intervals. The rocks above the Curruel foriution consist of reddish-brown flne-Brilned cross-bedded to flet-bedded sundstone, Ineluding several strata of reddish thin-bediled shaly siltstone. These roeks, which are 550 to 600 leat thick, are assigned to the Intrada sundstone.

The carnel foriation is not conaidered to be water bearing and the well Logs (tuble 2) do not Indicate the occurrence of water in the forration. The Bntrada sandatone on tha other hand is a relatively good aquifer. The sand grains are usually elean and well sorted, and are only caoderately cenented by caloium carbonate and ninor arounts of ferrie oxide. The vell Logs (table 2) show that aubstantsul asounts of water were encountered in several zonos within the Bntrade sandistone. In woll. 221-25, the Sanastee school well, o11. and gas were encountered batwean 1,727 and 1,739 reat, 150 faet wbove the contuet. Wast of the mapped area, several saall seeps have been observed along the contact. The Intrada sandstone crops out over t large region west and northwest of the Sanastee area, furnishing a substantial recharge area for the colilection and storage of water. The bedis in a large pert of this recharge area dip to the 
east, causing the water to nove eastward, dowalp toward the sanastee area where the vater 13 under artestan pressure.

The Todilto Linestone $210 \mathrm{~s}$ conformably upon the Fntrada asudetone and Is the only part or the kanakah foriation recoignised in this area. This Minestone formerly was considered a nentar of the overlying lorrison formation but now is considered a netaber of the Wanakah fortution which is aciuivalent to the upper purt of the Ban Rafael group. $1 /$ Stekes $2 /$ is also of the opinion that the Fodilto Iineatone should be placed in the San Rafuel groups he believes that the sediwentary environuent is sore related to the Ban Rapael sedinentation than to eonditions in Jorrison time.

The Todilto 21 testone in the Sunastee aran is 15 to 20 feat tilick and conalsts of bluish-jray, fine-grained to aphanltic, thin-beddod isapure linestone. This unit is resistant to erosion and forvs a prorinsut, bench in the sandstone alopes, and in sorse places forras a reslatant eap rock on the Entrads sandstone. Ho velis are known to produce water from the Todilto and it is not considered an acuifer bectuse of the lapervious character of the rocic. Horrisou forsation

The Korrison formation of Late Jurassie age lies confornably upon the Todilto linastone. A definite boundary is evtablished in this area by the contact batween the ifuestone and sandstone of the Morrison. In soas areas the Morrison formition is easily subdivided 1nto several neabers. $3 /$ Weh of these

1/Baker, A. A., Dane, C. H., and Reaside, J. B., 3r., Revised correlation of Jurasste formation of parts of Utah, ArIzona, Now Hoscieo, and Colorado: Aruor. fasoc. Patroleun Geologists Bull., vol. 31, no. 9, pp. 1664-1668, 1947.

2/Stoikes, W. L., Morrison formation and related deposita in and adjacent to the Galorado Plateau: Geol. Soc. Anerica Bull., vol. 55, p. 984, 1944.

$3 /$ Gregory, H. B., the San Jusin country, a geograghle und Eeologic reconnalsance of southeastern Utaha U. 8. Qeol. Swrvey Prof. Paper 188, p. 58-60, 1938. 
nembers is defined by 1ts oim distinctive 11thology, which includes aeolian sandstone, fluviatile sandstone, siltstone, madstone, and conglonerate. In the Sanastee area, hovever, it is difficult to subdivide the Norrison formution Into nembers becuuse there are no sharpiy contrasting lithologic changes. The Lorrison foration erops out oniy in the wastern part of the area. In this locality the rocks consist of pinklsh-jaray to whita, mediua-grainec, thinbedded, weakly cenented sandatones that aliernate with gray, black, green and red, thin-bedded siltstones. Thase ulternating beds fora a rough irmegular slope, usually yartiy concesied by talus. The thickness of the liorrison forration in the Sanastee area is 1,100 to 1,200 feet. In general, the Iower 600 to 700 feet consists largely of sandstone, whereas the upper part contains nearLy equaiy anoints of siltatone and sandstone.

The Morrison formation contains the essential featuras of a relatively good aquifer. The grains in the sandatones are fajrLy well sorted and $2003 e l y$ cemented. The 312tstones usualiy cont in enough sand graing to make them sonewhat pervious. Table 2 shoirs that water was encountered in scveral of the thicker sandstone units that occur throughout the forration. In adiltion to the outorops shoin on plate 1, outcrops west of the area mapped provide an excellent recharge area. These beds dip to the east, causing the jround water to nove in that direction. The water 1 ander artesian pressure, as evidenced by flowing weila $12 M-25,22 H-83$, and $12 k-34$. Sanastee Wash croases the Horrison 6 to 7 miles west of the school, providing an inportant source of recharge. It $\mathbf{i a}$ believed that water could be obtalned from the Aorrtan formation alnost anywhere in the Sanastee area, and that in all probability the isater would be under suffieient artesian pressure to flow from a well. 
Dakota andatone

The oldest Cretaceous rocics in the Sunastee area are represented by the Dakota sandetone, which is sepersated frok tha Mlorrison foraition by an erosional unconfornalty. The contact is not everywhere easily detestad because the 2ithology of the Morrieon forration and Dakota sandstore is siralar in usany places. Where the unconforrity can be detected, the arosion channels have a relief of several inches to several feet. In the Sanastee area the Dakota sandstone is composed of I1 ght-gray, medium-grained, thin-bedied, weil-eoraented sandstones that alternate with gray and black thin-bedded siztatones. Thin soars of Lowgrade coal occur at irregular intervala. The sanditones forn realattunt ledges and the interwenins silty beds forra slopes. The thicicness of this formation, as detorasned froa wel. logs (table 2), ranges fron 16 feet to more than 100 feet. Because the Lithology of the Dakota sandstone is siuslax to that of part of the liorrison rocks, it is difficult to detemalne the thickness accurately.

The Dakota sandstone is known to be a bood aquifer over nany lerige areas. In the Sanastee area the formation 1 s relatively thin but contains thick units of sandatone in a fea places. These sandatones provide reservoir space and allow water to nove relatively freely. A study of the well logs Indicates that these thieker sandstone units contain a sall anount of water. If wells were spaced at wide intervals ft would be possible to obtain water in 1incited anounts from the Dakota sandatone. The water probably would be under artesian preasure, as the strueture of the Dakota eandetone 18 conforaable to that of the Horrison formation.

Manecs shale

The Kancos shale 11 es conforiably upon the Dakota sandstione. The boundary 1s easlly observed owing to the sharp contruat between the black shaie and the underlying 2ight-gray sandstone. The linncos shaie has an almost honogeneous 
Ithology and la conposed of dark-gray to black flasLle earbonaceous shale. In the Sanastee area the Mancos shale is split Into two pirts by a tongue of

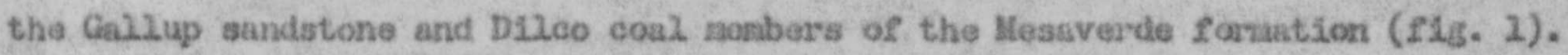
The lover put of the linneos is bluish-gray fisolle shale, with an average thickness of 750 seat. The upper part is geayiah-brown arenacoous fiastle shale and siltstone, with an averace thicloness of 950 feet.

Although the Uaneos shale is generally conaldered older than the Kusavorde fortation, the upper gart of the shala in the Sanastes area is youngor than the underlying Gallup gandatone and DLlco cos. ratabers of tho Hesaverde foriation $(f I g, 1)$. The intertonguing relation and depositional hietory of these Gretacoous sedinents are discussed wore fully by Piket/ than in tils report. In brieq, these deposits are related to the tranagreasion ard regression of the eea that covered this area in Upper Cretaceous tine. The shale was depositad durfine a period when the sos had transgreasad to the south, whareas the tonguas of scrudstone represent a regressive stage when the seas withdrew to the north.

The Haneos shale is not an aquifor but acte as en inpervious burrier between ground waters in the urder2ying and overly4ng aandotonos.

\footnotetext{
4 PLike, W. S., Jy., Intertonguking sarine and nonsarine Upper Creataceous deposits of Ied Kexdeo, hrLzonk, and southrestern Colorado: Geol. Soe. Âra:-1ea Mlenoir 24, pp. 23-25, 1947.

Asertea M
} 


\section{Kesavarde forration}

In the Sanastee area the Callup sandstone and D1lco coal narabors of the Mesaverde forkation occus as a tongue within the Kancos shale (fig. 1). Tils tongue is divided on the busis of lithology into three units:

1. The Lower pirt consists of a 2ight-gray, fine-gralned, thin-bedded sandstone that has been corzaluted with the Gajiup andstone mesaber of the liesaverde fortation by PLke. 5 2. Thin units of alternating sandetonea, curbonkceous siltatonea and scattered coal seams which are correlated with the Iover part of the Dilce coax wamber. 6/ 3. A 11.ght-gray, coarse-gruined, crosa-bedded sandstone which, sccorcilag to Plike, zaty correspond to the "stray sandstone" of Bears. I The total thickness of the three units averriges about 200 feot. They have bean raferzed to Lobaliy as the Tocito gandstone lentil of the Wancos shale, Iroa the exqoaures In Tocito Nash. Fowevar, as Flke has correlated thera with the Galiup sandstone and DIlco coal nembera of the Hosaveraie formation, the name Toelto does not spirent to be valid. For the purpose of thís Feport Plke's correlation has bean used.

Tre Uazluy sandstone rember and the "atray andstone" of the Mesaverde fornation have good water-bearing properties. The and gruins in both are Clean and well sorted and are not well cemented, eapeclaliy in tho "stray sandatone." Thase characteristics allow ground wator to tave through the sundstone freely but because it is relatively thin the reservolix capucity is not $2 a x g e$. The recharge area of these metbers 1 not as large as recharge areas of the Momison and Bntreda formitions. In the viesinfy of Tocito trading post and along the northeast flank of Foc1to dome the occurronce of seeps in the Gullup sandstone meaber shows that it contains sore water.

5/PLke, W. S., Jx., op. eit., p. 28, 1947.

$6 /$ Idesa, p. 28.

IJ Sears, J. D., Hunt, C. B., and Hendrieks, T. A., Transgressive and regressive Cretaceous dejoulta in southern San Juan Busin, N. Lex.: U. S. Cool. Survey Prof. Paper 193-5, p. 213, 1942. 


\section{Quaternaxy Deposits}

ALLuviuin of Hecent age occiars along Sanastee Wash und Toctto Wash (p1. 1) and conststs of a alxture of shile, silt, sand, pebbles, and boulders dejosited In Iong shaliow depresalons along the atruas courses. The finer inaterlals were derived fron the surrounding Cretaceous and Juraksic recks. The coarser saterials are aostiy igneous fragnents frosa the voleanic rocks that crop out wast of the Sunatee area. The alluvius ranges in thicicness from 5 to 25 feat.

tiater noves freely through the uneonsolidated alluviur, as evidenced by several seopa along the washes. Nearily all these aeops are located whare Inpervious atsie bods force underRlow to the surface. Several dug weils obtain water from thie alluviun.

\section{Impous 8locks}

Outcropg of 1 jnoous rocks In the arua consist or one sand plus and two narro: dikes south of focito kash. These rocks are belleved to be Geneticaily related to the voleanic necks that lie southerst of the Bunustee area. The igrieous rocks do not yteld water.

\section{Struetines}

The Sarastee area 2 Ses fin the weatmeantral part of the San Juan Easin and contrins several local anticlisial folis (pl. 1). The largest of these is Besutiful Ifountain antioline, a rathor narrom fold. The axis of this anticiline trends approxclsately $N$. $20^{\circ} \mathrm{N}$. throkzh the cantral part of the ares. Fear the northerr boundery of the area the acis swings eastoward to about $\mathrm{N}$. $20^{\circ}$ İ., continuing for a diatance of 5 thiles noth of the mapped area. The northern half of the anticline la folded asymuebraaliy, as the eastern flank dips $9^{\circ}$ to $73^{\circ}$ and the western flank dips $1^{\circ}$ to $2^{\circ}$. The southern hale of the antleline is nearly symatrloal, as both Ranks dip fros $3^{\circ}$ to $3^{\circ}$. 
degrees. The southern half of the anticline is nearly symetrical, as both flanks dip from 1 to 3 degrees.

A small, prominent elongated dome, known as the Tocito dome, lies in the northeast part of the area. The major axis of this dome trends about $N \cdot 40^{\circ}$ W. The length of the dome is about twice as great as the width, and the northeastern and southwestern flanks are nearly symetrical. The southern end of the dome is several hundred feet north of Sanastee Wash, and the northern end is 1 mile northwest of well $12 R-84$. A minor east-west fault with a displacement of about 50 feet cuts across the center of the dome. This fault is not shown on plate 1.

A relatively shallow asymmetrical syncline trending $N \cdot 30^{\circ} \mathrm{W}$. lies between Beautiful Mountain anticline and Tocito dome. Another asymetrical syncline trending about N. $20^{\circ}$ W. lins west of the southern half of Beautiful Mountain anticline. The eastward dip of the beds in the western limb of this syncline ranges from 1 to 11 degrees. In the western part of the area the dip of the beds becomes increasingly greater.

These eastward-dipping strata are believed to be a part of the Fort Defiance monocline. The folded structures of the Sanastee area are pertinent to the movement of ground water. The greater part of the recharge area is located on the eastward-dipping strata that form the lower part of the Fort Defiance monocline. The recharge area is several hundred feet higher in elevation than the wells in the Sanastee area (table 1). It is evident that the ground water should be under artesian pressure at the wells. Furthermore, wel1 tests indicate that the hydrostatic pressure is sufficient to cause ground water to move through the folded structures.

\section{WATER SUPPLIES}

An investigation was made of the wells and most of the springs in the Sanastee area, and the results of these studies are given in tables 1,2 , and 
3. The investigation showed that only the Dakota? sandstone, the Morrison

formation, and the Entrada sandstone will yield sufficient water to supply the proposed school. Water was encountered in one or more of these formations by four deep wells (12M-25, 12R-83, 12R-83a, 12R-84, table 2). One of the four deep wells $(12 \mathrm{M}-25)$ is on Beautiful Mountain anticline at Sanastee school. The other three wells are on Tocito dome, about 7 miles northeast of Sanastee. The following sections discuss the water supplies of the area.

\section{Well at Sanastee 5 chool}

Well 12 M-25 has been flowing almost without interruption since 1925 . A study of the well $\log ($ table 2 ) shows that most of the water is produced from the Morrison formation and the Dakota? sandstone, which overlie the Todilto limestone. The oil and a small amount of the water is produced from the Entrada sandstone.

Tests were made on the well to determine the maximum shut-in pressure, the maximum rate of flow, and the physical characteristics of the aquifers. The flow from the well was shut off for 4.8 hours by a valve at the orifice of the well. Data obtained from observing the build-up in pressure (see fig. 2 a) made it possible to compute the hydrostatic pressure that would have built up if the flow had been uct off indefinitely. This hydrostatic pressure

was computed to be equal to the pressure required to support a column of water 129 feet in height above the measuring point. After the pressure data were collected, the valve was opened and measurements were made of the decline in rate of flow with respect to time. The rate of flow became approximately constant at 57 gallons per minute about 4 hours after the valve was opened (see fig, 2 b). Computations of transmissibility, using a method developed by Theis-, indicate that the aquifers at Sanastee are moderately permeable, relative to other sandstone aquifers. Using a discharge of 57 gallons per

I] Theis, C. V., The relation between the lowering of the piezometric surface and the rate and duration of discharge of a well using ground-water storage: Am. Geophys. Union Trans. p. 520, 1935. 
point. Aftor the presaure data nero colledted, the valve was oposied and measuroments were made of the deuldue in rate of flow with respect to tine.

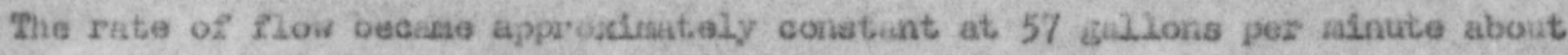
4 ho rs after the valve was opened (see 215 . 2b). Compututions of transuds-

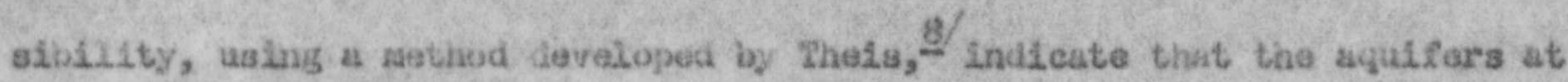
Sanastee are modurately perrabable, rolnLive to other sundstone aquifers. With a discharge of 57 galions por ninute (ILE. 2b) and the computed atatic head of 129 foet above the nacusuring point, the specific capacity of the weIl was computed to be about 0.45 galion per minute frat foot of drawdown.

The results of the testes on wall. $124-25$ indieate that the aquifors in the Sanuatee area would yleld sufricient water to supply the proposed nan achool.

\section{Halls on Tocito Dome}

The threa wells on Tocito dowe $(12 \mathrm{k}-83,12 \mathrm{k}-83 \mathrm{a}$, and $228-84)$ were drilled in search of oll. Two of the wella vers abandoned as ofl tuats and, because fresh rater was encountered, they were sold to tha Foderal Covurnaent for use as vatar wolls. The third reil $(127-63 a)$ is eapped, and no tests could be mide to detormine the anount of avallable vater.

The discharge and the wexdrau hydrost atic pressure were measured on wells $22 k-3 y$ and $12 R-34$. Tha open-llow rate of discharge of well $224-83$ was 19 gallons per minute and the cobputed hydrostatid pressure st the end of 3 hours whs echilvalent to the pressure rociulred to support a colunan of watar about 37 foot above the 2 and surfuce. The epen-flou rata of dischange of well $1228-84$ vas 11 gallons per minute and the conputed hydrostatic pressure at the and of 3 hours was equivalent to the pressure required to support a J Thels, C. V., The relation between the Lowering of the plezoratric surface and the rate and duration of discharge of a well using ground-water storage: Am. Veophys. Union Trans., p. 520, 1935. 
coluan of water about, 30 seat above the lna surfice. The raeasureanents shoved that the combined flow of both wells would supply the 26 gallons per rinute needed for the proposed school.

Calculations were aade to estiuate the dravdown in each well, assuaing that watar for tha proposed school nould be supplifed frost esther well by puaplnis part of each day and coliecting the Rou durime the reanining part of the day. Assualing an 8-hour daily puapling perioci and a 4-hour poriod during which the plezonetric surface is recovering from the puaping level to the level of

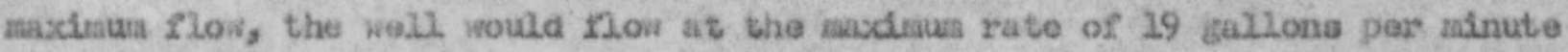
for 2.2 hotrs per clay and at a lower rate diring the latter stugea of the 4-hour period of recovery. The discharge during the 4 -how recovery period la not Included, bat constitutes a factor of safety, in the following calealutions to detartatine the raquíred puty discharge and the resulting dravdown.

Total water needed per 24 hours: 37,500 gallons Water collected during 32 -how nowing period $(60$ min. $x 12$ hrs. $x 29$ ggm.): 23,680 galions Water collected durling 4-hour recovery periad: 0 Wator that raust be pusged during the retaining 8 hours $(37,500-13,680):$ 23,820 gallons

Fuaring rate requilred $(23,820$ sei. $\div 60$ isin. $x$ int3. $): 49.6$ sullons per

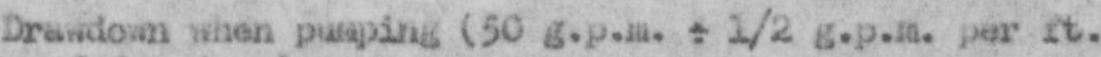
of drawdown): rinute

200 feet Applying a sinallay proeadure to vall $12 k-84$, , the requirad puaging rute would be $62 \mathrm{gnzl}$ ona per winute and the drandom would be about 270 feot belon the land starface. 


\section{Snrings and shollor vells}

The locations of the springs studied in the Senastee orea sre shown on plate 1, sid recorts of these springs ere given in tables 1 and 3 . Tvo springs (S-1 end S-2) 1sgue from the lower part of the Koncos shale, flong the benks of Sennstiec Wash. The operator of Sanertee trading post reported that the flow of spring S-2 1ncreased in 1948, after a sel swograph crex set off subgurface explosions in this vicinity. A regident Indien reported that a seisnogreph teet hole var orllled at the epring. Whatever the cruse, the euthors assure that as a result of the sel smogreph testing progrsm a passace vas opened through the shnie, which alloved weter from the Dokote sandstono to flow to the lans purfece. A third spring $(5-3)$ ismes from alluvial fill In the bottom of the vash, and represents underflow forced to the surfice by 1mpervious shole beds. A fourth spring $(S-5)$ is on the porthesstern limb of Focito done, end isrue from the Gallus snmetone rember of the Yeseverde formation.

Severs seeps flong Sanatee Kssh issue from the alluvisi f111, and one vell (S-4) formerly vas used to obtaln water from the fill. The underfiow of Senrstee Creek vas estimated to be sbout 50 gellons per minute ot the time of the 1nvest1gation. Inpervious ehale beds force underflov to the surface et several locallties between Senastee school and U. 5. Highvey 666. Marshy lands supporting Ewang gress occur in some of these localities, and incrustations of nelt along the of ges of the stream are common.

GQDALIFY OP WATTR

$$
\text { J. D. Bey }
$$

The anrlyges of seven vater semples in table 3 shov the chemicel cheracter of ground vaters in the yieinity of Sanastee. Two semples, which vare collected 
from vell 12N-259 wonthe eprert, shov no signiflcent differences in quality. KeIIs 22B-83 and 12R-84, northeast of Sanastee, yleld vater with chenical character $51 \mathrm{~m} 11 \mathrm{a}$ to water from vell 12M-25. The vater from these three vells 1. derived principelig from the Dakota sandistone and the Korrison formation. The veter from vells $12 R-83$ and $12 R-84$ has a sightly higher disolved-solids content thrn water from well $12 K-25$. This dfference mey be ceused by one or both of the following factors: (1) Local variation in soluble salts in the Dakota gendstone and the Korrison formetion; ond (2) veriations in the proportions of vater coming from the different vater-besing beds in the forkations. The los concentrations of ealcium and nengesium in the water from these three vells 1 nilicntes thet notursl softening of the whter by bese exchenge Day occur vithin the Dekota end Korrison formations.

Spring S-1 ierues from Nencos shele and yields vater contalning rather large anounts of diesolved solids, mostly colclum and sulfate. Spring S-2. nearby, gields weter lover in alssolved-solids concentration snd wuch softer. the principal constituents belng sodiur, bicerbonote, and sulfate. As already othied in this report, mping $S-2$ is believed to obtuin some water from the underlying Dricots senistone, and the dischrige ney represent a mixture of waters from the Dakote senointone and the lancos shole. Spring S-3 isgues in the bottom of Sanastee Wegh, and the anolgsis of asmple from this opring is believed to represent the cuslity of whter in the Guaternary alluvium along the vash. Thls vater is sorewhot nore highly minerallzed then the vater from epring $S_{-1}$ and from spring S-2. Spring $5-5$ is reported to 1 s cue from the Gallup anditone member of the Nesaverde formation on the northeast glde of Toclto dome. On the basis of the anelyses, water from epring $\$ 5$ is of better cquility then veter from the other springs in the area. 
Aradyses of water from the Dakota sandstone and the Korrison fomation In the Sanusteo area show Low dissolved aolicts and barriness. The water from

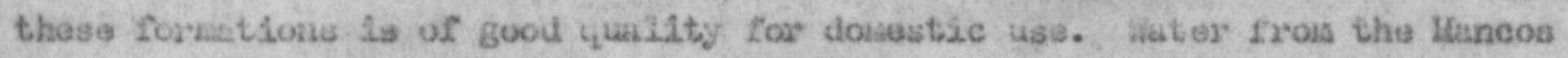

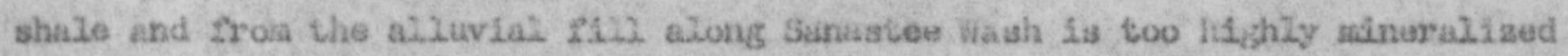

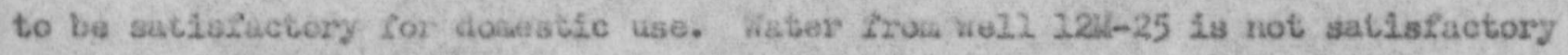

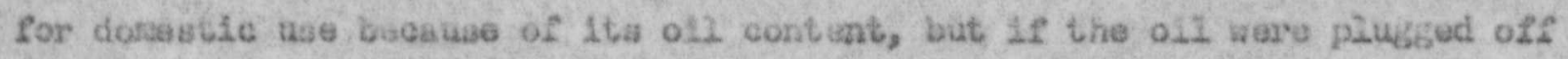
the waise would be of the best quakity of those saipled in the area.

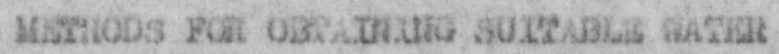

\section{Weyt at Sanatee johool}

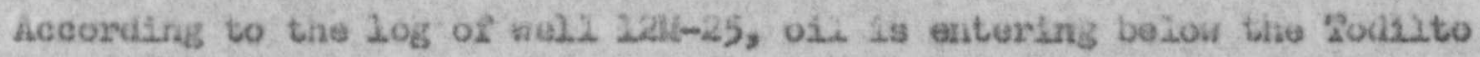
1inestone. A concrete plus placed at the top of the Lisestone, at a depth of $3,4,20$ Reet, would seul off' the ush. However, this would wlso seal off one

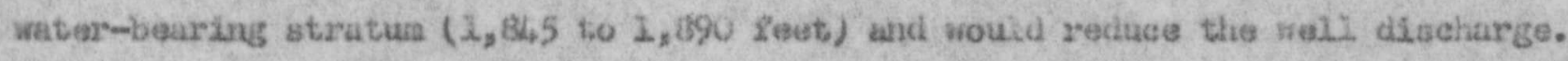
To Insure a tifint seal the "schutese" isethod, used by cotasercial oll-irell cementIng colapanios, should ba triked. After the los ar part of tho wall kna been t1ghtly sealed off and the upper part has boen thoroughy eleaned out, the wall probably will produce an adequate water supply of suatable quelity for the proposed school.

A new wall could be drilled at Sunastee school in the event that weil 12x-25 is used for Arrigatson or is sbandoned. The nen well showld be about half a nile froa wall $22 k-25$, and showld be drilied to a depth of about 1,400 Peat, In order to ponetrate the Horrison fornation. 
The discussion of the wells on Locito doce under the heaifing MVlater Supplies" Indieates thut an adequate supply is alroady developed for the proposed school.

\section{Bite between Sansistea Sohool and U. S. HA hway 666}

Construction of a new school. enst of the abandoned school would require the dr1uzing of a valy. Investigation indicated that water could be obtuined at any point botween the ahandoned schor 2 and 1.8 . Mighray 666 . If the site selected is about 3 silias west of the highuay, the following stratigraphic section would be encountered.

\begin{tabular}{|c|c|c|c|c|}
\hline Forrution & Agse & $\begin{array}{l}\text { Wuter-bearing } \\
\text { character }\end{array}$ & $\begin{array}{c}\text { Thleknass } \\
\text { (feet) }\end{array}$ & $\begin{array}{l}\text { Depth to base } \\
\text { of fornition } \\
\text { (feet) }\end{array}$ \\
\hline $\begin{array}{l}\text { Mancos shale } \\
\text { (uppar part) }\end{array}$ & Cretanceous & Non-vater-bearing & $100-200$ & $100-200$ \\
\hline 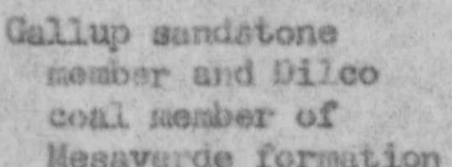 & ภำ. & PosstbIy vater-bearing & & 1,00 \\
\hline $\begin{array}{l}\text { Wancos shile } \\
\text { (Lower pert) }\end{array}$ & do. & Hon-vater-bearing & $750 \pm$ & $2,050-2,150$ \\
\hline Dakota anndstones & do. & liatex-buaring & $60-200$ & $1,130-1,250$ \\
\hline Morrison foriantion & Jurassic & do. & $1,250 \pm$ & $2,260-2,400$ \\
\hline
\end{tabular}

According to the seotion above, deternined from a study of well $20 \mathrm{ge}$, areal distribution of formations, und atrueturai rolations in the Banastee aroa, a well at th1s site should be orilled to a alifium deptil of 1,100 feet and a possible maxthum depth of 2,4,00 feet. Ister mould be encountered in the Dakota sandetone but in all probability the najor jart of the water would have to be obtained by dituling finto the Morrisor forration.

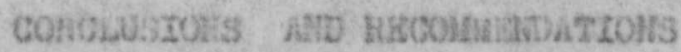

The follorine conclusiosis and recoanendations are asede for the developant of a suituble water supply for the Janustee school:

1. About 37,500 gallons per day of potable water will be needed in the Sanastee 
area when the proposed school is constructed.

2. The Jansatee weII (125-25) provides an adequate quantity but the water la contabinated with olx. Weter froes the well would be of sultabie quality for dobestic use esceejt for the Associated oil.

3. The oil in the surtabtes wisl car be sealed orf by placing a piug in the well at the top of the Fodute linestone, at a dopth of about $1,4,00$ fout.

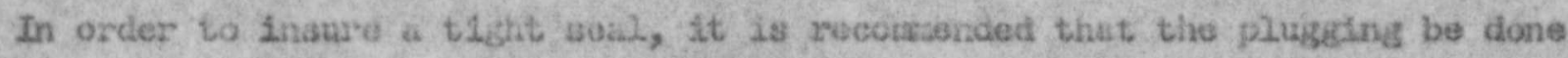
by an ofl-wisi2 cesenting cuapany.

4. A new tell could bo dribled at banstee to furnish a water supply for the propesed school if tha Bansistee well is used for other purposes. A new well should be at least half a ndle from the exiating weil, and should bo drilled to a depth of lisout 1,400 feet.

5. The raquired abount of water for the proposed school is available frota two flowing weils about a mile apart on focito done. This water is considered suftuble for donostic use. Bither of these wails could supply the achool if a puap we:a Inotalled.

6. Construotion of a nus school east of Sansatea school woild reciulre the drilling of a wall. Hater could be obtained at any point betireen janastee sehool and U. 3. HIghway 666. If the aite sulacted were 3 rilies veat of the highway, the well should be dritled to a minimua dopth of 1,200 seet or to a cascinata depth of 2,400 foet. The water wo Ld be under artealan presaure, and the major part would be obtained frua the liorrison-forastion. Analyses of water samplea from the other wil.2s in the area shos that water froa a weil in this vieinity probably would be sultable for dogestie use. 
20

Table 1.--Records of wells and springs in Bani ste area, San Juan County, How Mexico (AI1 wells are drilled unties otherwise noted in "liecriks" column)

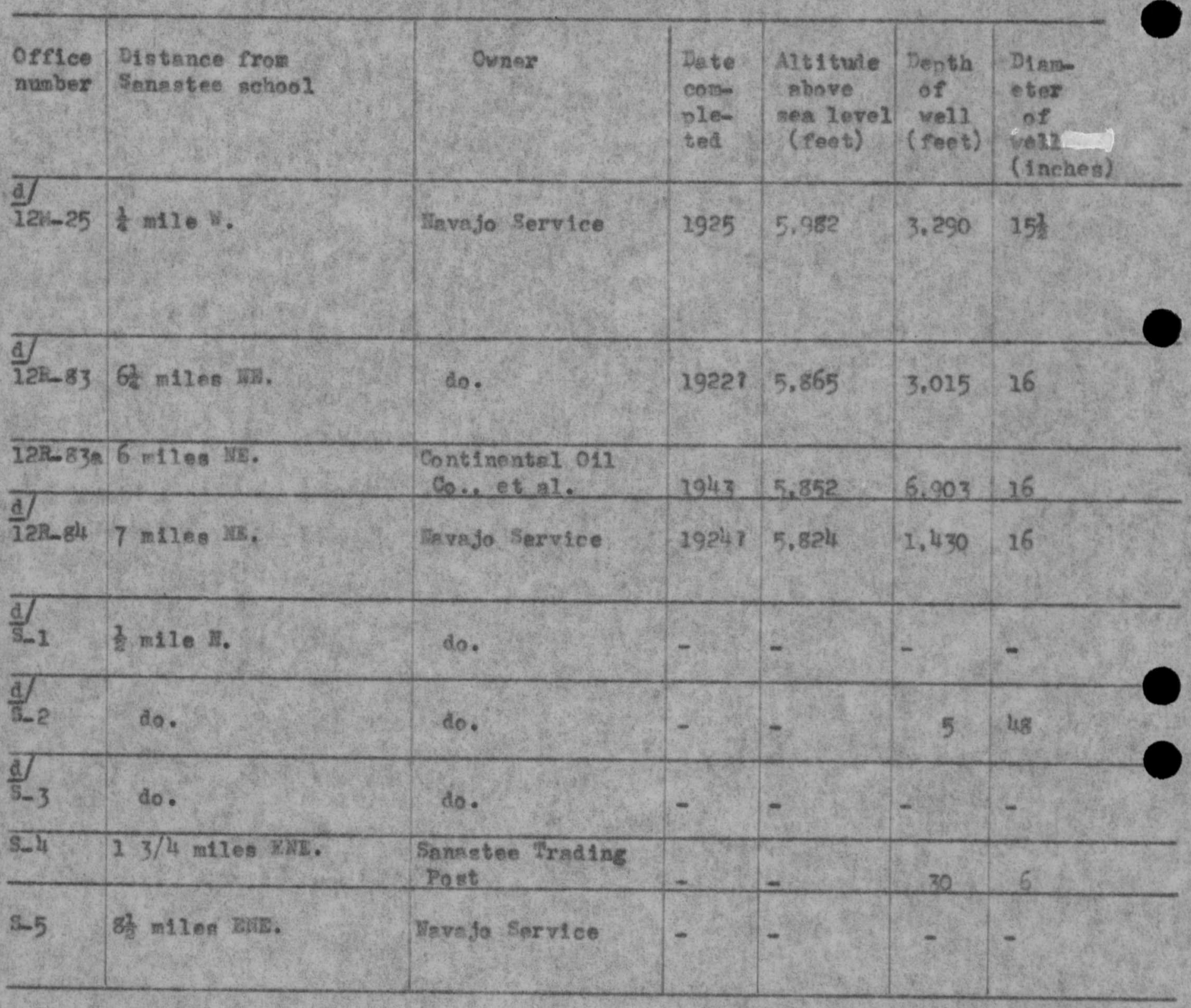

I Hessurements are feet of head above outlet of discharge pipe, measured with pressure gage.

b) Plowing. 
Records obtalned by H. A. Yashe, G. A. Lerus, and A. D. Pullido (See plate 1 for locations of vells and springs,)

\begin{tabular}{|c|c|c|c|c|c|c|}
\hline $\begin{array}{l}\text { Office } \\
\text { nurabex }\end{array}$ & $\begin{array}{l}\text { Weter ley } \\
\text { Depth } \\
\text { below } \\
\text { messur- } \\
\text { ing noint } \\
\text { (feet) \& }\end{array}$ & $\begin{array}{l}\text { Del } \\
\text { measure- } \\
\text { ment. } \\
1949\end{array}$ & $\begin{array}{l}\text { Punp } \\
\text { and } \\
\text { power } \\
\text { b/ }\end{array}$ & $\begin{array}{l}\text { Use } \\
\text { of } \\
\text { water } \\
\text { el }\end{array}$ & $\frac{1}{2}{ }^{2}$ & Remsrks \\
\hline $12 M-25$ & +128.95 & Aus. 30 & $r$ & $D, 3$ & 69 & 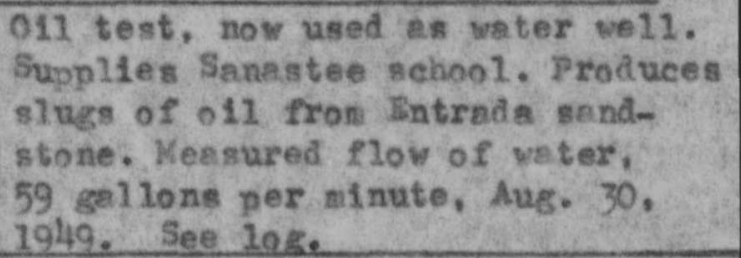 \\
\hline $12 R-83$ & 7.37 .55 & Sept.24 & $\overline{3}$ & 1,5 & 77 & 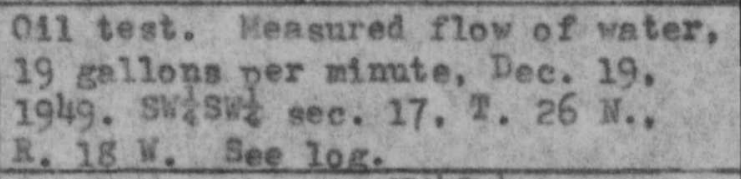 \\
\hline $122-83 a$ & - & - & Hone & in & 75 & 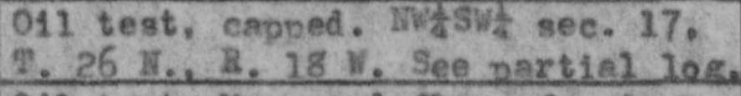 \\
\hline $12 R-84$ & 729.5 & Avg. 31 & 7 & I, S & $76 \frac{1}{2}$ & 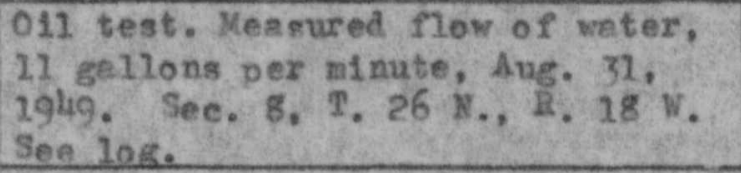 \\
\hline S-1 & Spring & - & 7 & N & - & $\begin{array}{l}\text { Fowe 1nto Senrstee Wash. Bistimated } \\
\text { discharge, tug. } 31,1949,5 \text { gallons } \\
\text { per nimute. }\end{array}$ \\
\hline $5-2$ & do. & - & 7 & $D, 5$ & - & $\begin{array}{l}\text { Deepened by digging. Bstimated } \\
\text { discherge, Aug. 31, 1949, } 20 \\
\text { gallons per minute. }\end{array}$ \\
\hline $5-3$ & do. & - & 7 & $\mathrm{~N}$ & - & $\begin{array}{l}\text { In bed of Sanastee Kash. Rstimated } \\
\text { discherge, Aug. 32, 1949, } 50 \text { gal- } \\
\text { lons ner mimote. }\end{array}$ \\
\hline 5.4 & 10 ef & Aug. 31 & None & 2 & - & $\begin{array}{l}\text { Produced vater from elluvial fill } \\
\text { of Sanagtee Wash. }\end{array}$ \\
\hline$S-5$ & Sprting & - & 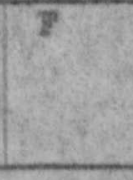 & $D, S$ & 34 & $\begin{array}{l}\text { Issues from sandetone outcrop on } \\
\text { enstern side of Toeito done. } \\
\text { Estimated discharge, } 2 \text { gallons per } \\
\text { mimute, Dec. } 19.1949\end{array}$ \\
\hline
\end{tabular}

c) D, domestic; S, stock; I, 1rrigation; 菏, none.

d) See table 3 for snalysis of vater from this vell or spring.

ef Weter level reparted. 
Fable 2,-liogs of wells in Sanastee area, San Juan County, Hev Mexico

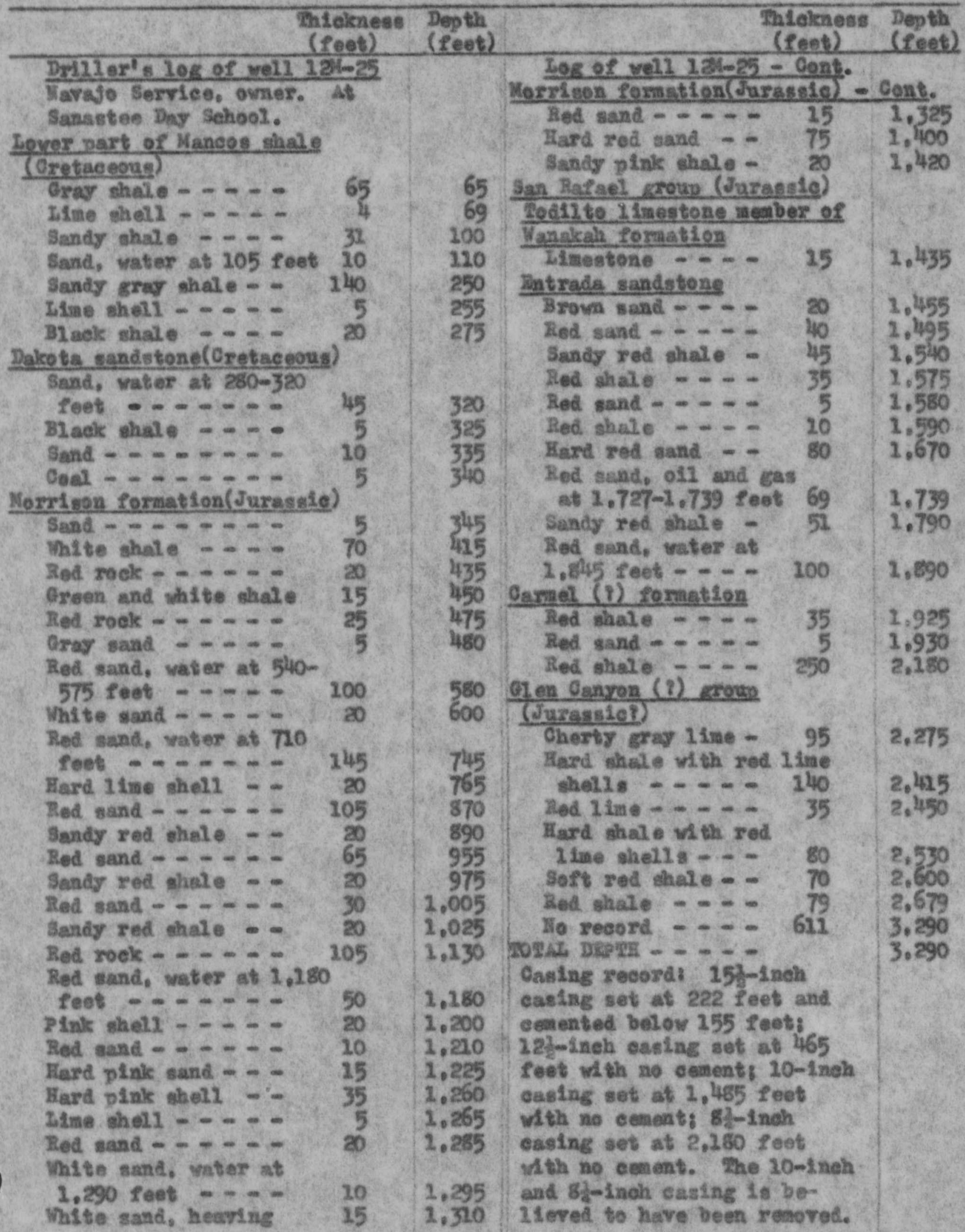


Table 2.-Logs of vells in Sanastoe ares-lontimed.

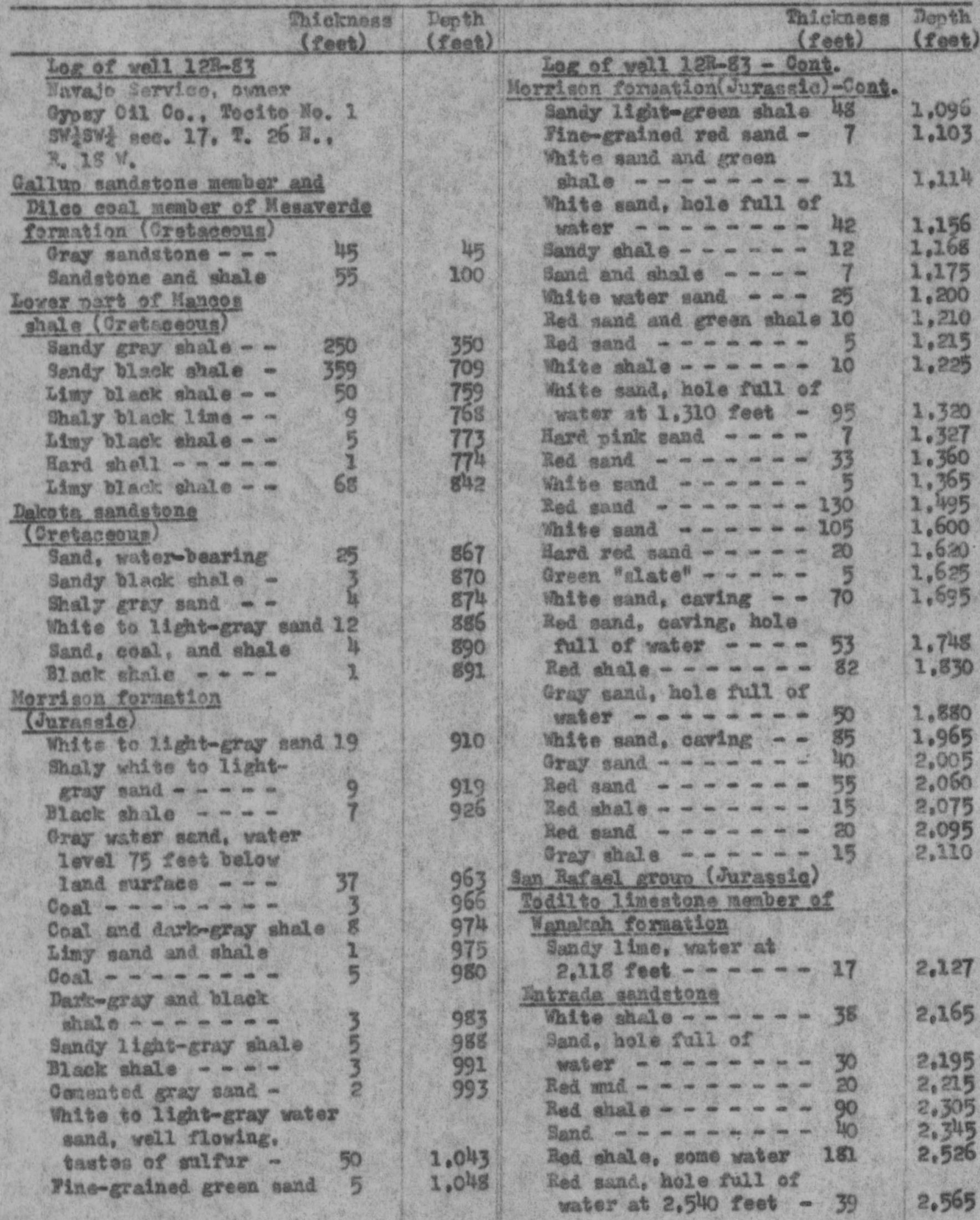


Table 2.-Logs of vells in Sanastee araa-Contimued

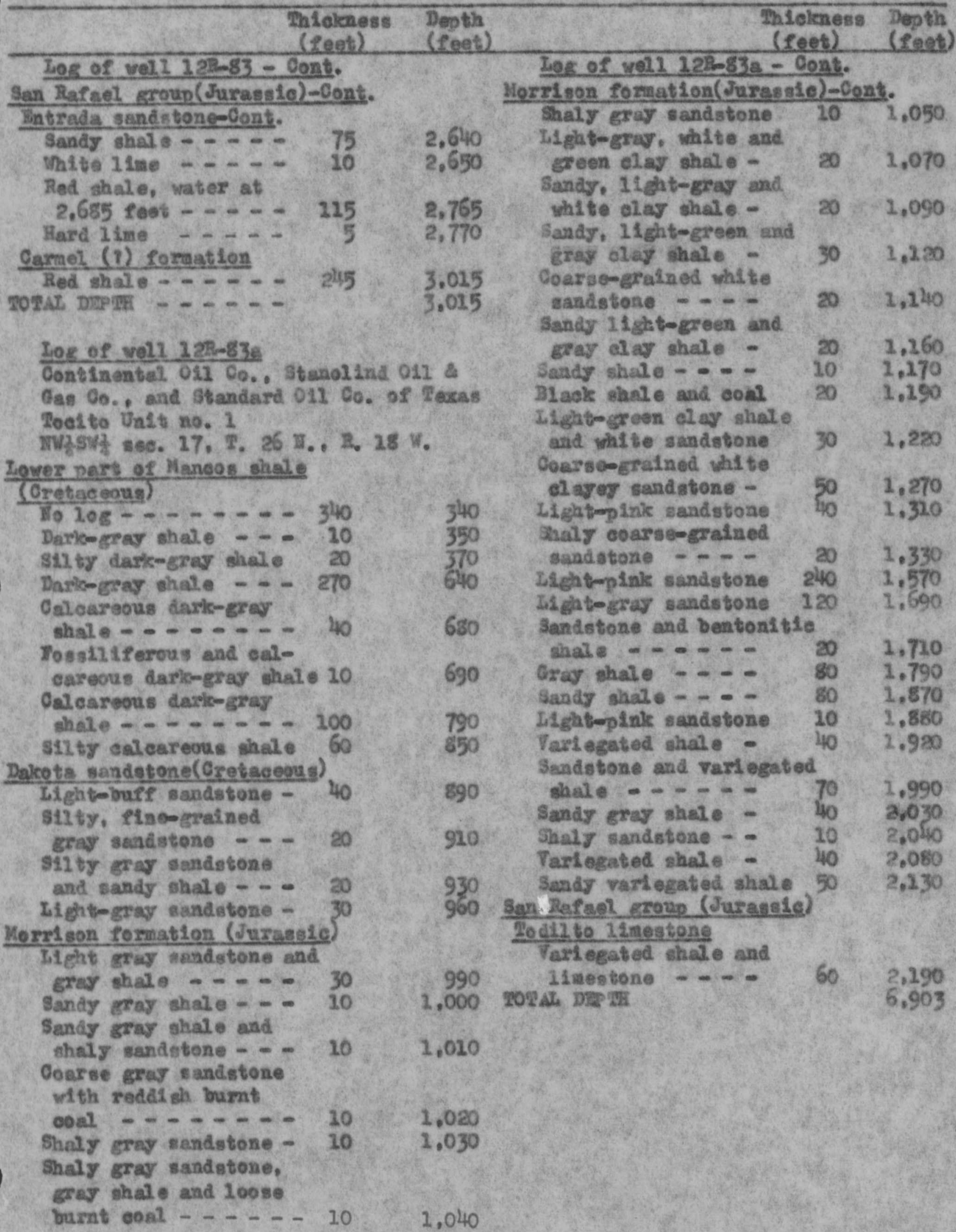


Fable 2.-Logs of vells in Sanastee area-Coatsnued

\begin{tabular}{|c|c|c|c|c|c|c|}
\hline $\begin{array}{r}\text { Thiok } \\
\text { (Pee } \\
\end{array}$ & eet) & $\begin{array}{l}\text { Depth } \\
\text { (reet) }\end{array}$ & \multicolumn{3}{|c|}{$\begin{array}{l}\text { Thiolenese } \\
\text { (feat) }\end{array}$} & $\begin{array}{l}\text { Depth } \\
\text { (feat) }\end{array}$ \\
\hline Dxiller' 108 of vell 223 & $8-84$ & & Leg of vell 1 zin-s & $4-$ Cont. & & \\
\hline Xavajo Service, ovmer. & & & rex son foriation ( & (Jurasege) & $=0$ & \\
\hline Continental 011 Qo. Yeli r & no. 1 & & Coal $-----=$ & $-\infty$ & 5 & 1.015 \\
\hline Tooito fleld, Béc. 8, 9. & - $26 \%$ & r. & Gray shale $=--$ & --- & 8 & 2,023 \\
\hline 21un sands tone neaber and I & Dileo & & $\mathrm{Coal}-\ldots-\cdots$ & -- & 2 & 2. \\
\hline nember of 1 esarerde fornatio & $\operatorname{lon}(\mathrm{Cr}$ & cecu: & Gray vhate - - - & --- & 20 & 45 \\
\hline Sandrtione $-\cdots-\cdots$ & 46 & 15 & Ilne-grained gray & $\operatorname{sand}$ & 35 & 1.080 \\
\hline Itght-blue shale - - & & 53 & Inse shell - - - & --- & z & 1,082 \\
\hline Gray sand - - - - - & 7 & 60 & Gray ghale --- & - & 6 & 2,088 \\
\hline Shale and eray band & 18 & 78 & Bieli $=---$ & -- & 1 & 2.089 \\
\hline Gray eand $-\ldots$ & 7 & 85 & $\operatorname{Sen} d-\cdots---$ & -- & 1 & 90 \\
\hline Oray shaile and sald & 25 & 120 & IL ght-gray shate & $-\rightarrow-$ & 22 & 2,112 \\
\hline oves nart of Mences shale. & Crata & ag) & Yeliov day - - & $--\infty$ & 5 & 2,217 \\
\hline Darkoblue ahele $-\infty-$ & 20 & 130 & Hard sand - - - & $-\infty-$ & 8 & $8=1$ \\
\hline Gray shai $--\cdots$ & 35 & 15 & Vetret send - - - & --- & 5 & \\
\hline Daxte-gray shale - -- & 207 & 22 & If $r$ ecest -- & $-\infty$ & ? & \\
\hline Litme thall $--\cdots$ & & & Pink ghala - - - & $-2-$ & 20 & \\
\hline Gray thal & 1.56 & & Gray 1 isae shelt & --- & 5 & 47 \\
\hline Gray 2 ime $-\cdots \cdots$ & & 588 & Droksen 1 tine -- & --- & 3 & 150 \\
\hline Blask shal e $--\infty-$ & 42 & & ed I lase shell. & --- & 2 & \\
\hline Daxio-gray shate - - - & 90 & & in shale -- & --- & 4 & \\
\hline Gray ghale ---- & 204 & & d I ime shell & --- & 2 & \\
\hline Faxd shell $-\ldots-\cdots$ & 2 & & White shale - - & $-\infty$ & 2 & \\
\hline Blus thale $---\cdots$ & 14 & & Green shale - - & -- & 5 & 65 \\
\hline Blus shal s, bentonite & 30 & & a shale --- & -- & 5 & 170 \\
\hline Blue shate $-z_{-}-1$ & 30 & 880 & Gray shale - - . & -- & 20 & \\
\hline kota sandstone (Cretaceous) & & & Inard sand $\ldots$ & -- & 5 & \\
\hline Fino-grained wite water & & & Pink ehele - - & & 7 & 1.9 \\
\hline 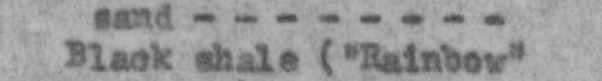 & 6 & & $\begin{array}{l}\text { White shale - - } \\
\text { Hard end (water) }\end{array}$ & $-\infty$ & 30 & \\
\hline shoving) $---\cdots$ & 1 & 857 & Il ght-blue shale & $-\infty$ & 5 & \\
\hline Fiard gray send - no & & & Saad, hesty flow & of vater & $5 i$ & \\
\hline Increage in vater - & 3 & 890 & Hard sand -- & $-\infty$ & 5 & \\
\hline Gray shale $-\infty-\infty$ & 6 & 896 & Gray shale - - - & $-\infty$ & 15 & \\
\hline rrien forration (Jurans & & & Cray sand -- & & 15 & 1.315 \\
\hline $\begin{array}{l}\text { Iard sand }---_{-}^{-}- \\
\text {Fino- gralined vhlte gand }\end{array}$ & 7 & 907 & $\begin{array}{l}\text { Gray sand with la } \\
\text { shalle - - - - - }\end{array}$ & ayers of & & \\
\hline $\begin{array}{l}\text { Gray sandy shale - - } \\
\text { Eard sand and shale }\end{array}$ & 3 & 910 & $\begin{array}{l}\text { Red sand - - - } \\
\text { Totad Dister }\end{array}$ & -- & 70 & 1,4 \\
\hline
\end{tabular}




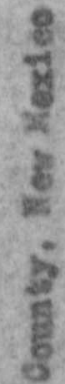

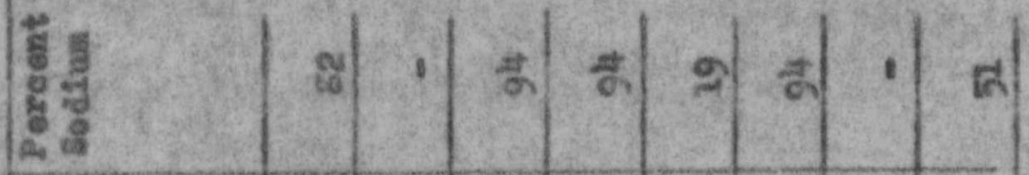

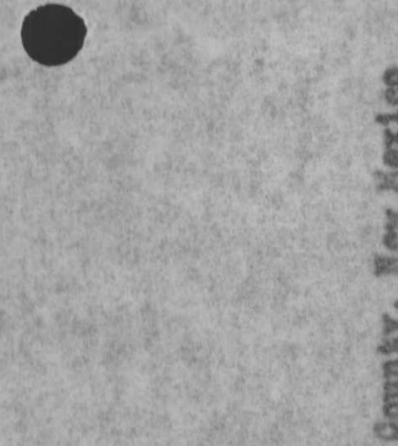

$\frac{5}{4}$

mi

of

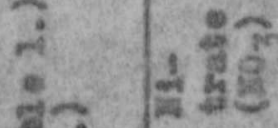

ร)

ex

(ब) 5

IS:

류요

be

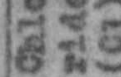

$8<-8$

요용 9

हो स्त

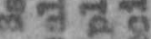

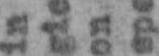

웅

해용

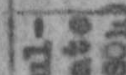

मืक

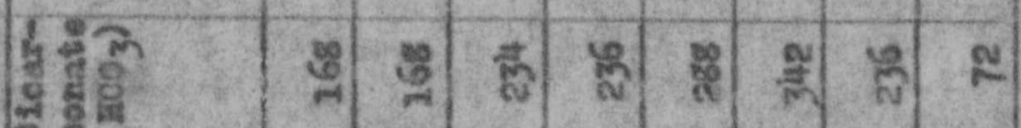

A.

嵒 8

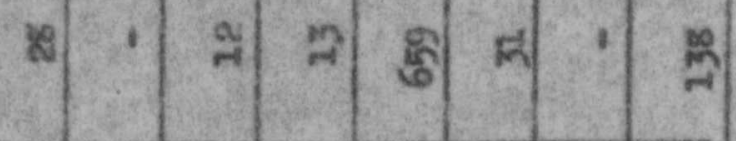

, o ${ }^{2}$

응 85

हु

s. $\mathrm{E}$

a 2 물

है요요

ह क

\& 8

g.



8

远

- 18 8

\begin{tabular}{ll|l|l|}
8 & की & &
\end{tabular}

1

है, 훙료

2क थै

할 हैं

o.

홍

正

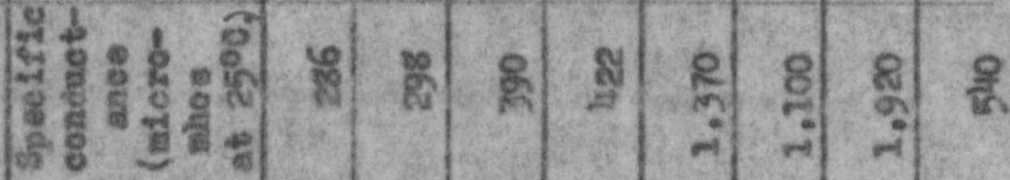

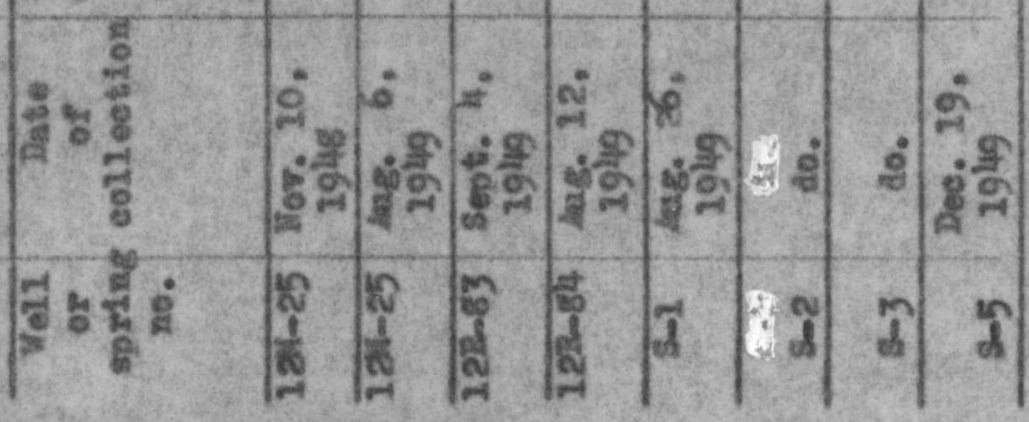



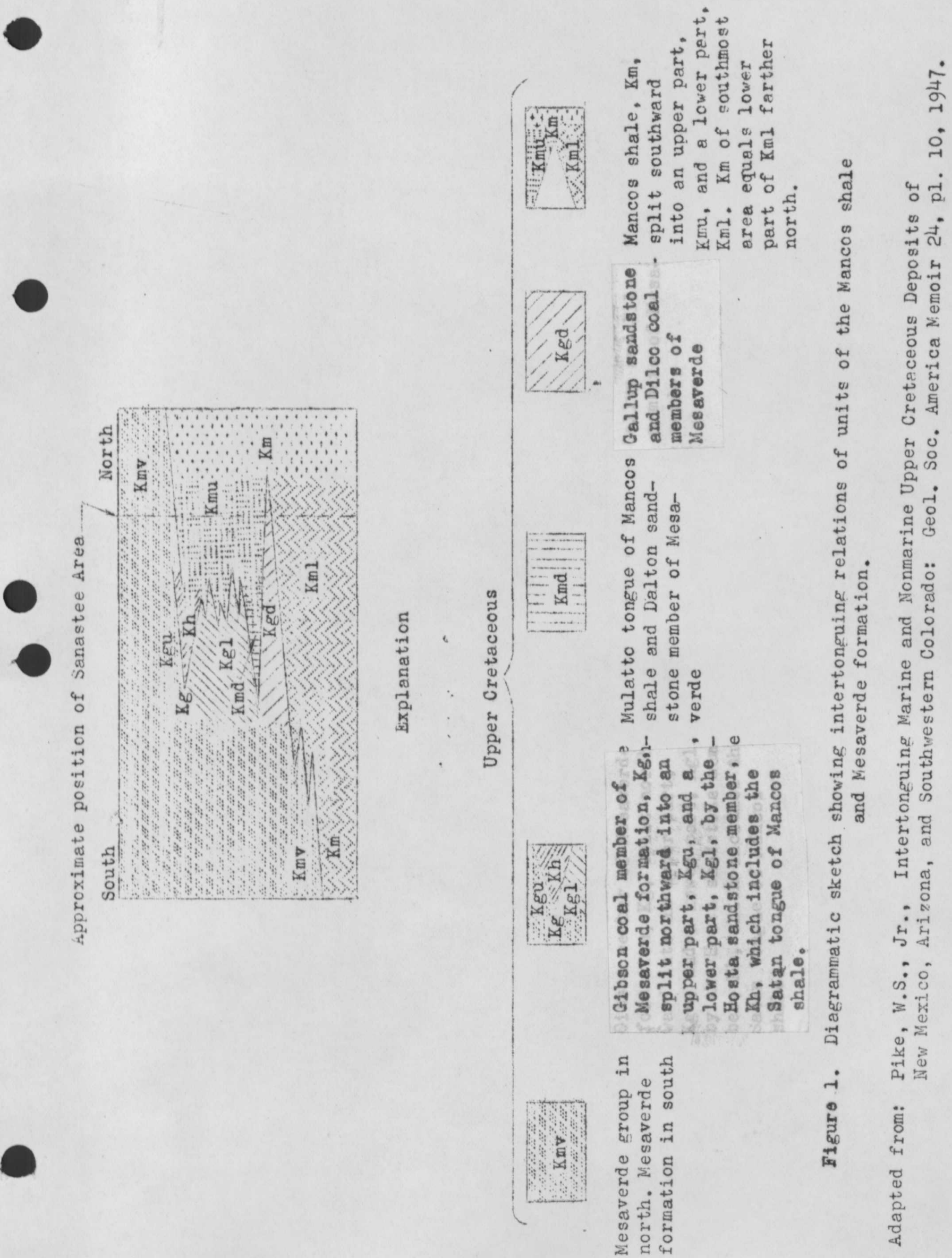


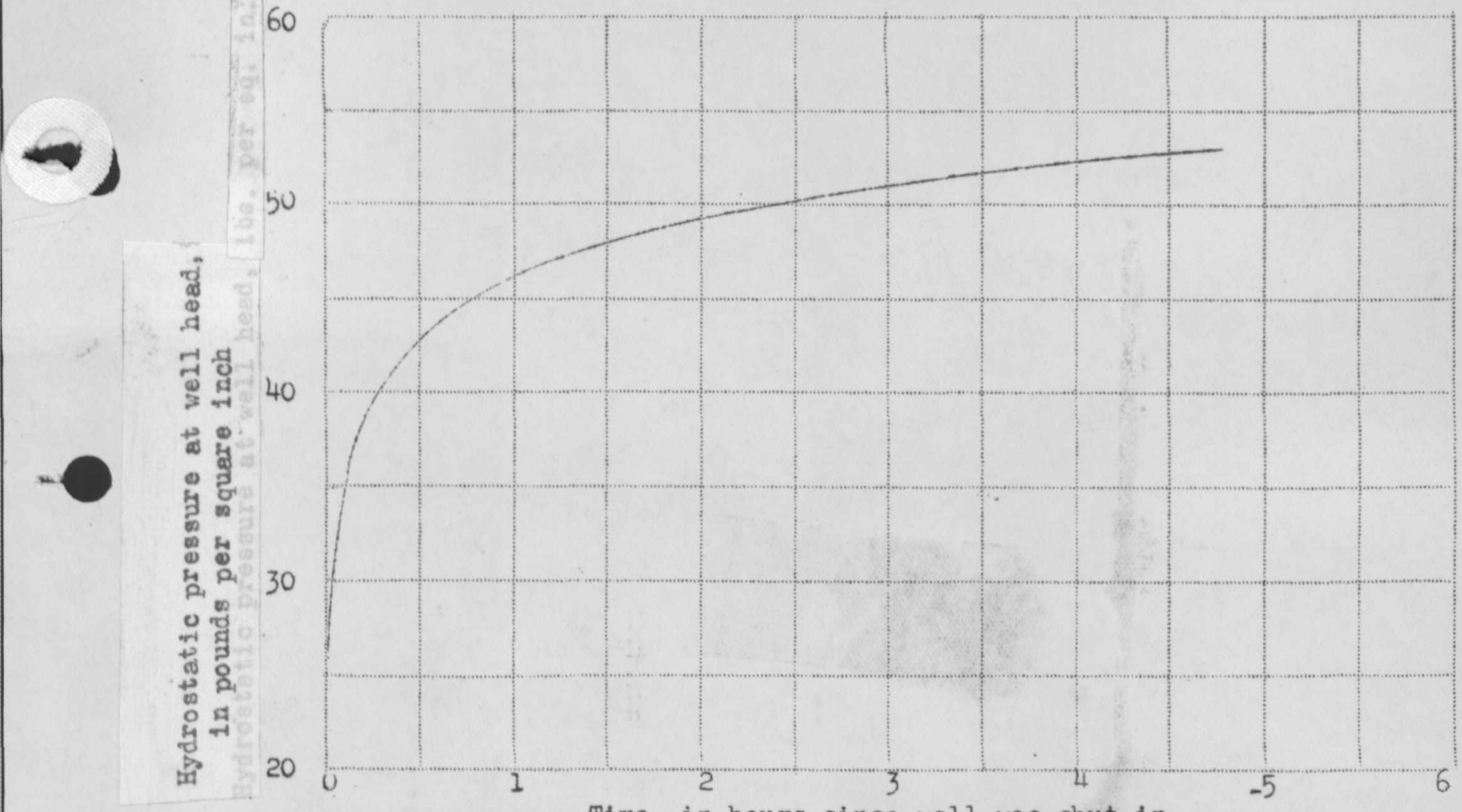

Time, in hours since well was shut in

(a) Measurements of Hydrostatic pressure

9

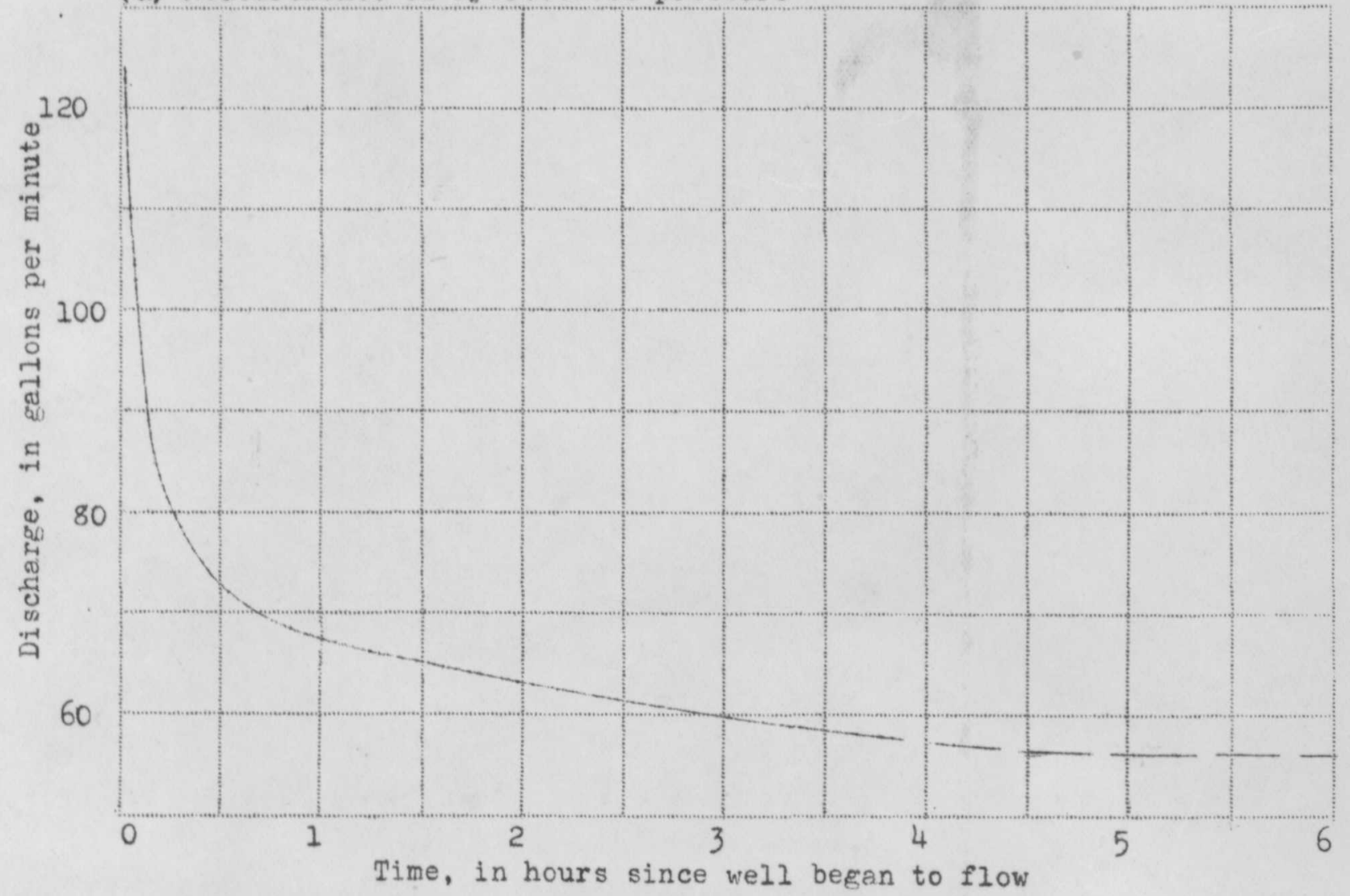

(b.) Measurements of discharge

Figure 2.- Graphs showing results of tests on Well 12N-25, Sanastee, N. Mex. 